\title{
Education, entrepreneurship and the environment
}

\section{La educación, emprendimiento y el medio ambiente}

LANDIN-ALCANTAR, Herlinda †** VAZQUEZ-MIRAMONTES, Nicolás, MARIN-OROZCO, Emmanuel Rodrigo and PALOMINO-NUÑEZ, Sergio Joel

Universidad de Guadalajara, Mexico.

ID $1^{\text {st }}$ Author: Herlinda, Landín-Alcántar / ORC ID: 0000-0003-4453-6408, CVU CONACYT ID: 995045

ID $1^{\text {st }}$ Co-author: Nicolás, Vázquez-Miramontes / ORC ID: 0000-0001-8782-6398

ID $2^{\text {nd }}$ Co-author: Emmanuel Rodrigo, Marín-Orozco / ORC ID: 0000-0001-9422-3974, CVU CONACYT ID: 272465

ID $3^{\text {rd }}$ Co-author: Sergio Joel, Palomino-Núñez / ORC ID: 0000-0002-8955-3706, CVU CONACYT ID: 587725

DOI: $10.35429 /$ EJS.2021.14.8.26.31

Received January 25, 2021; Accepted June 30, 2021

\begin{abstract}
The trend of the state is to promote the creation of companies in general, which help the development of selfemployment of graduates. Universities are training professionals with less dynamic production techniques in the agricultural sector, development and the needs of the population are increasing, which requires innovation in the production of healthy, profitable foods with less impact on natural resources. Professionals with business training must be developed in a manner that will allow them to generate their own jobs, look for technological alternatives that help improve the production of healthier and organic foods, and use products of natural origin that are replacing the pesticides and drugs that are reflected in the final products for the consumer. Among the development alternatives, you can venture into business projects that seek to improve the production and development of organic products, and inputs with added value made through natural processes. It can be mentioned that there is knowledge of organic agriculture, and the trainers at the University have technical knowledge based on previous and current research. However, there is little information on the certification of agricultural activities for the volumes that are required in the country.
\end{abstract}

Entrepreneur, Environmental effects, Health, Organic products

\begin{abstract}
Resumen
La tendencia del estado, es fomentar la creación de empresas en general, que ayuden al desarrollo del autoempleo de los egresados. Las Universidades están formando profesionales con técnicas de producción menos dinámicas en el sector agropecuario, el desarrollo y las necesidades de la población van en incremento que exige innovación en la producción de alimentos saludables, rentables con un menor impacto en los recursos naturales. Se deben desarrollar profesionistas con una formación empresarial que permitan generar sus propios empleos, buscando alternativas tecnológicas que ayuden a mejorar la producción de alimentos más saludables y orgánicos, utilizando productos de origen natural que vayan sustituyendo los pesticidas y medicamentos que se reflejan en los productos finales para el consumidor. Entre las alternativas de desarrollo se puede incursionar proyectos de negocios donde se busque mejorar la producción y el desarrollo de productos orgánicos, e insumos con valor agregado elaborados a través de procesos naturales. Se puede mencionar que existen conocimiento de agricultura orgánica, y los formadores en la Universidad tienen conocimientos técnicos en función de investigaciones anteriores y actuales, sin embargo, se encuentra poca información de certificación de las actividades agropecuarias para los volúmenes que se requieren en el país.
\end{abstract}

Empresario, Efectos del medio ambiente, Salud, Productos orgánicos

Citation: LANDIN-ALCANTAR, Herlinda, VAZQUEZ-MIRAMONTES, Nicolás, MARIN-OROZCO, Emmanuel Rodrigo and PALOMINO-NUÑEZ, Sergio Joel. Education, entrepreneurship and the environment. ECORFAN Journal-Spain. 2021. 8-14:26-31.

$\dagger$ Researcher contributing first author. 


\section{Introduction}

The production of organic products goes beyond taking care of the diet of a population. In recent years, public health problems have been associated with food, due to the use of agrochemicals such as pesticides that are used to protect crops from pests and insects, fungi, weeds, and diseases, from which it can be generated condition such as cancer, neurotoxic and teratogens (harm to the fetus) (2016).

On the other hand, in the production of food in the livestock area, a product that contains clenbuterol hydrochloride is usually used in animal species such as cattle, sheep and pigs, for productive-reproductive purposes, this product is mainly used in animals for fattening, since it is an anabolic that promotes muscle growth and inhibits the accumulation of fat and its meat is intended for human consumption. Fajardo et. Al. (2011)

When we talk about globalization that affects agricultural production due to the importance in the trade of products on a world scale, since a traffic of goods, capital and services is generated as mentioned by De León 2018, this can generate a short-term alternative term to underdeveloped countries such as Mexico, which seeks to increase its productivity in agricultural production based on its natural resources and production techniques such as protected crops where feasible, that is, that surface that has the climatological characteristics, water, and personnel looking for a harmless or organic product. In the case of producers, the health problem has an idea of some diseases generated by using agrochemicals, however, they do not know how to address the problem of diseases caused by chemical products used in the agricultural sector. The students given their academic training, such as, Agricultural Engineers and Veterinary Doctors in training, a survey was given to 130 students, where the total population is 6000 students. The intention of this survey was to detect what was the vision and perception of the students about activity in agricultural production and its alternatives and if they considered it business, as professional training will be food production on a larger scale. The objective of this study is to promote the development of new techniques, research, and training to increase production and productivity, seeking to reduce environmental damage.

\section{Entrepreneurship}

Entrepreneurship can be associated with the "ability of a person to envision or anticipate the future of a business"., Pérez and Merino (2017). Students in the agricultural area who are interested in developing food production must consider some factors such as the type of food products to be developed, healthy products, the destination market for the sale and distribution of crops, the natural resources from which they are available, labor for both planting and harvesting, the seasonality of product prices, the costs of inputs and services, lack of information on prices in the market, and lack of the guidelines for the production of products for export. INEGI (2019).

These factors are part of a business training that will make students have more planning before starting a production process as well as see the field as a profitable business.

\section{Environmental impact}

Traditional agriculture contributes to the erosion of natural resources, mainly soils, such as erosion by water, wind and poor agricultural practices. This is why natural resource conservation programs, have had little impact on soil conservation, water and other forms of degradation. Water erosion affects a large percentage of hectares due to this type of erosion, it occurs due to rain or surface currents of streams and rivers as well as the effect of irrigation in some agricultural fields, the vegetation protects the erosive effect of water, therefore the conservation of plant resources is necessary, (Bolaños-Gonzalez et. al 2016). Oldeman (1994) points out that products were designed for international comparison purposes in the project called "land evaluation", who reports that water erosion is the main factor induced by human activities of agricultural soil practices. However, regarding the surface affected by different erosion processes, according to SEMARNAT (2003), indicates that due to the different degradation processes, chemistry occupies the first place with 34.0 million hectares that represent $17.8 \%$ of the country. Followed by water erosion with 22.72 million hectares representing $11.9 \%$, wind 18.12 million hectares, representing $9.5 \%$ and physical degradation is 10.84 million hectares, representing $5.7 \%$. The rest, which is $55.1 \%$, does not show signs of apparent degradation. 
Erosion, its causes and surface

\begin{tabular}{|l|r|r|l|}
\hline \multicolumn{1}{|c|}{$\begin{array}{c}\text { Type of } \\
\text { Erosion }\end{array}$} & $\begin{array}{c}\text { Millions } \\
\text { of Has }\end{array}$ & $\begin{array}{c}\text { Percentage } \\
\text { of Surface } \\
\text { Erosion }\end{array}$ & \multicolumn{1}{|c|}{$\begin{array}{l}\text { Damage } \\
\text { Caused }\end{array}$} \\
\hline Chemistry & 34.04 & 17.8 & $\begin{array}{l}\text { Fertility and } \\
\text { productivity } \\
\text { efficiency }\end{array}$ \\
\hline Water & 22.72 & 11.98 & $\begin{array}{l}\text { Soil loss and } \\
\text { removal }\end{array}$ \\
\hline Wind & 18.12 & 9.5 & $\begin{array}{l}\text { Loss of soil } \\
\text { and removal }\end{array}$ \\
\hline Physical & 10.84 & 5.7 & Compaction \\
\hline
\end{tabular}

Table 1

Source: Own elaboration, with data from SEMARNAT 2014

The practice of crop rotation should be programmed according to the periods of each crop, as well as, the $\mathrm{pH}$ of the soil. The excessive use of chemical fertilizers damages the soil and the microorganisms existing in it. In the case of mixed and relief crops, there is little opportunity for the recovery of the soils, as well as climate change, unlike the dates of sowing and obtaining water both for the subsoil and for the irrigation of the crops.

Another environmental impact that is being presented with greater emphasis is soil erosion due to the use of intensive technologies such as greenhouses and tunnels that have a high productivity at the beginning, however, over time erosion and the use of control of variables (wind, air, sun, water, intensive use of agrochemicals) decrease the productivity of the soils considerably. Bláquez M. (2003)

\section{Health}

A part of the damage to health is generally caused by the volume and form of application of organophosphate insecticides, which are sprayed on crops but also on the environment, damaging the applicator and nearby communities, (Silveira 2018). In various studies published in recent years, some of the health problems derived from the different forms and uses of pesticide application are described. Some of the effects of the use of pesticides can be ematological and hormonal alterations, genetic damage, behavioral alteration and brain damage. (Garcia 2018). "Experts consider that the chemicals present in all kinds of everyday consumer products are the main source of contamination." (Quintanar 2014).

In the surveys applied to the students, they show that they know organic products are healthier, however, they mention not knowing many organic products or substitutes to combat pests and diseases in the agricultural sector that affect health to a lesser extent.

\section{Organic products}

Pérez and Landeros (2009) describe organic agriculture as the prohibition of the use of pesticides, as well as, the use of organic fertilizers and the implementation of agricultural practices that can restore and maintain an ecological balance of biodiversity. In the case of organic products, there are various sources of statistical information not adequately recorded or their evolution, (Schwentesius et.al 2017). It can be said that there is confusion in the concepts of organic agriculture and certified agriculture (safety), because certified agriculture uses some agrochemicals, which despite being allowed by international organizations are still agrochemicals.

\begin{abstract}
"At present, various environmental, social, economic, cultural and political factors have motivated interest in the development of organic agriculture, recognizing itself as an economically efficient, socially just and ecologically sustainable alternative with the potential to mitigate negative impacts attributed to conventional agriculture", (Arias 2015).
\end{abstract}

Given the characteristics that occur in production systems, such as, the excessive use of agrochemicals causing damage to the environment and the health of producers and consumers in general, it is considered necessary to raise awareness in the academic preparation of students, establish production technologies and less aggressive inputs in food production in general as well as the diffusion of these production systems. In Mexico, a typology of three forms of organic agriculture has been developed:

a) Purist Its production is not usually certified and is mainly for selfconsumption, it is based on local resource technologies.

b) IFOAM, (International Federation of Ecological Agriculture Movements). This is produced by indigenous people and lowincome people who produce coffee, cocoa, vanilla among other crops. It is defined by certification processes and a specific system that differentiates it from nonorganic methods.

c) Business Organic Agriculture Industry. This type of agriculture is considered of recent creation (late 90's, in highly remunerative crops, such as vegetables, fruits and agave among others. It is characterized by the substitution of conventional inputs for external natural resources. (Mexicampo, 2020).

LANDIN-ALCANTAR, Herlinda, $\quad$ VAZQUEZMIRAMONTES, Nicolás, MARIN-OROZCO, Emmanuel Rodrigo and PALOMINO-NUÑEZ, Sergio Joel. Education, entrepreneurship and the environment. ECORFAN JournalSpain. 2021 
Crops developed with traditional agricultural techniques. It is based on soil tillage, practices such as plowing, tracing are included in other agricultural practices. Generally, agricultural machinery and implements are used, sometimes certified seed is used, as well as a preestablished technological package for the type of crop to be produced.

Protected crops. They are those in which part of their production cycle is in a modified environment which surrounds the plant. There are options such as greenhouses, hydroponics, and mulches. It requires a greater investment than traditional production, however it can generate higher yields in production depending on the cultivation and management. The production of this type of agriculture is normally for the external market, which represents a greater profit when the price is stable.

Organic crops. In this type of crops there are restrictions on the use of synthetic fertilizers and pesticides to produce goods, preserving the natural characteristics of the environment in which it grows. Given its natural and healthy characteristic, the possibility of diseases decreases if no agrochemical is used, only made from natural products, which leads to a higher market value.

\section{Methodology}

Due to the increase in agricultural production, specifically production with organic and / or innocuous characteristics, a questionnaire was applied in an Agricultural University Center in the state of Jalisco with students who are training in these areas. The type of research that was applied is descriptive, taking a sample of 130 students from a total population of the center of approximately 6000 students. To analyze the information collected, a formula was used for when the total data is known, which is the following:

$n=\frac{Z^{2} P Q N}{(E)^{2}(N)+Z^{2} P Q N}$

$\mathrm{Z}=$ Value of tables Confidence 90\% (1.645)

$\mathrm{P}=$ Positive probability (+) $60 \%$

$\mathrm{Q}=$ Negative probability (-) $40 \%$

$\mathrm{N}=$ Total data

$\mathrm{E}=$ Error $7 \%$ $n=\frac{(1.645)^{2}(.60)(.40) 6000}{\left.(.07)^{2}(6000)+\left((1.645)^{2}(.60) .40\right)\right)}$

$n=\frac{3896.676}{30.04944}$

$n=129.67 \cong 130$

Sample size 130

\section{Results}

Of the 130 surveys, the students were asked their gender, resulting in $54 \%$ being women and $46 \%$ men. Regarding question one, it was asked if they know about the production of agricultural or innocuous products, $70 \%$ answered that they did know and the remaining 30\% said they do not know. Question two mentioned if they knew any type of organic product, where $42 \%$ said that they knew of any type of product, and they mentioned compost, which is considered an input, and 58\% do not know. The third question mentions if they have brought any material related to the production of organic food and $90 \%$ mentioned yes, and $10 \%$ do not know. Question four asked if the consumption of organic and innocuous products is healthier and aids in reducing diseases, and $100 \%$ agreed. The fifth question mentions if they would like to develop research on this topic and 90\% mentioned they would like to do research, where $50 \%$ of that $90 \%$ are interested in the area of organic fertilizer production, $15 \%$ in herbicides and insecticides, $10 \%$ beneficial insects and $10 \%$ in agricultural practices, $15 \%$ answered that if they are interested in participating in the livestock area but do not know in which line, the rest are not interested in the research. In the sixth question, he mentions he would like to participate in a project in the development of organic and safe products and $85 \%$ of the respondents from the agricultural area stated that they would be willing to participate in a project. Questions did not show any type of research project in the livestock area. Questions arose as to why those people who said are not interested in participating, and the majority said because they do not know the subject or the market. The last question mentioned about the continuity of the traditional production of agricultural activities and $48 \%$ answered yes, while 52\% want to reform and change production systems to obtain higher yields and therefore obtain better income as well as meet new markets and demand. 


\section{Conclusions}

1. When conducting this research, it was detected that the students have a confusion in what corresponds to organic agricultural production vs safety. It is worth mentioning that organic products are free of pesticides or any inorganic input.

2. Women in the agricultural sector show greater interest in participating in organic food production.

3. Just over $50 \%$ of the respondents have an interest in improving production systems that allow them to obtain higher yields, produce healthier goods and obtain better income through training.

4. It would be advisable to increase the curriculum, programs on organic products and activities as well as to emphasize the difference in organic and safe products and promote the development of new production technologies.

5. A more active exchange between academics and students is recommended to strengthen the disciplines of organic production.

6. Promote training and research centers by the state that generate new studies and technologies in agricultural disciplines.

7. Promote the training of researchers in the area of organic production, requiring financial support from the state for training of human resources in this area.

\section{References}

Arias H. A. (2015). Productos Organicos en México. Dirección de Estudios Soberanía Alimentaria y Nueva Ruralidad. Centro de Estudios Para el Desarrollo Rural Sustentable y la Soberanía Alimentaria. CEDRSSA/DESANR.

http://www.cedrssa.gob.mx/files/10/97Producto s\%20org\%C3\%A1nicos\%20en\%20M\%C3\%A9 xico.pdf

Bláquez M. (2003) Capitulo X. Los Residuos Urbanos y Asimilables. Consejería de Medioa Ambiente.Los residuos pásticos agrícolas. Comunidad Europea. Fondo Europeo de Cohesión. Junta de Andalucia. https://www.juntadeandalucia.es/medioambient e/web/Bloques_Tematicos/Educacion_Y_Partic ipacion_Ambiental/Educacion_Ambiental/Educ am/Educam_IV/MAU_RU_y_A/rua10.pdf
Bolaños-González, M.A., F. Paz-Pallat, C.O. Cruz-Gaistardo et al. (2016). Mapa de erosión de los suelos de México y posibles implicaciones en el almacenamiento de carbono orgánico del suelo. Terra Latinoamericana 34: 271-288.

De Leon L. G. (2018) La globalozación y su influencia en la agricultura. Anuario Juridico y Económico Escurialense, ISSN 1133-3677. file:///Users/lindalandin/Downloads/DialnetLaGlobalizacionYSuInfluenciaEnLaAgricultura -6332793.pdf

ENA (2019) Encuesta Nacional Agropecuaria. INEGI. Secretaría de Agricultura y Desarrollo Rural. https://www.inforural.com.mx/inegi-yagricultura-presentan-los-resultados-de-laencuesta-nacional-agropecuaria-ena-2019/

Fajardo Z.A., Mendez C.F., Molina L.H. (2011) Residuos de fármacos anabólicos en carnes destinadas alconsumo humano. Grupo de Salud Pública Fundación Unversitaria del Área Andina, Bogotá, D.C. Colombia. http://www.scielo.org.co/pdf/unsc/v16n1/v16n1 a07.pdf

Garcia, H. J. Et al. (2018) Estado actual de la investigación sobre plaguicidas en México. Revista Internacional de Contaminación Ambiental. DOI: 10.20937/RICA.2018.34.esp01.03

https://www.researchgate.net/publication/32254 9538_Estado_actual_de_la_investigacion_sobre _plaguicidas_en_Mexico

Gonzalez S. E. (2020). MEXICAMPO INTERNACIONAL. La Agricultura Orgánica en Mexico.

https://www.mexicampo.com.mx/laagricultura-organica-en-mexico-2/

INEGI (2014). Instituto Nacional de Estadística y Geografía. Erosión del suelos en México. Boletín de prensa Núm. 295/14. Aguascalientes, Ags.https://www.inegi.org.mx/contenidos/salad eprensa/boletines/2014/especiales/especiales20 14_07_1.pdf

Oldeman, L. R., D. J. Greenland, and I. Szabolcs. (1994). The global extent of soil degradation. pp. 99-118. In: D. J. Greenland and I. Szabolcs (eds.). Soil resilience and sustainable land use. CAB International. Wallingford, CT, USA.

Pérez J. y Merino M. (2017) Definición de: Definición de visión empresarial (https://definicion.de/vision-empresarial/) 
Pérez V. A. y Landeros S. C. (2009). Agricultura y deterioro ambiental. Elementos: Ciencia y cultura 16 (73): 19-25

Semarnat y CP. (2003) Evaluación de la degradación del suelo causada por el hombre en la República Mexicana, escala 1: 250000. Memoria Nacional 2001-2002. México. https://apps1.semarnat.gob.mx:8443/dgeia/infor me_resumen14/03_suelos/3_2.html

Schwentesius Rindermann, R., Gómez CruzM. Ángel, Ortigoza Rufino, J., \& Gómez TovarL. (2017). México orgánico. Situación yperspectivas. Agroecología, 9, 7-15. Recovered from:

https://revistas.um.es/agroecologia/article/view/ 300571

Silveira-Gramont, M. I. et al. (2018). Plaguicidas agricolas: un marco de referencia para evaluar riesgos a la salud en comunidades rurales en el estado de sonora, méxico. Rev. Int. Contam. Ambient [online]. vol.34, n.1 [Cited 2020-06-09], pp.7-21. Available at: <http://www.scielo.org.mx/scielo.php?script=sc i_arttext\&pid=S0188-

49992018000100007\&lng=es\&nrm=iso>. ISSN 0188-4999.

http://dx.doi.org/10.20937/rica.2018.34.01.01.

Quintanar O. S. (2014) Sustancias químicas de uso cotidiano las cuales son tóxicas y dañan el medio ambiente. Universidad Autonoma del Estado de Hidalgo. ISSN 2007-7653 https://www.uaeh.edu.mx/scige/boletin/prepa3/ $\mathrm{n} 1 / \mathrm{m} 13 . \mathrm{html}$. 